\title{
State Title to Territory-The Historical Conjunction of Sovereignty and Property
}

\author{
Douglas R. Howland \\ Department of History University of Wisconsin-Milwaukee, Milwaukee, WI, USA \\ Email:dhowland@uwm.edu
}

How to cite this paper: Howland, D. R. (2020). State Title to Territory-The Historical Conjunction of Sovereignty and Property. Beijing Law Review, 11, 856-878. https://doi.org/10.4236/blr.2020.114051

Received: August 27, 2020

Accepted: December 8, 2020

Published: December 11, 2020

Copyright $\odot 2020$ by author(s) and Scientific Research Publishing Inc. This work is licensed under the Creative Commons Attribution International License (CC BY 4.0).

http://creativecommons.org/licenses/by/4.0/

\section{Open Access}

\begin{abstract}
Why, in the course of the $19^{\text {th }}$ century, did legal scholars come to treat State territory as State property? This essay recounts a history of "title" to territory, as sovereignty became territorial and the State became an owner of territory. The comparison of international law and private law encouraged the treatment of territory as property, and was substantiated through prize law, colonial acquisitions of imperialism, and the analogy between the State and individual, with international leases and eminent domain modeled after property transactions. Recent affirmations of aboriginal title, however, raise the possibility of realignment among sovereignty, territory, and title.
\end{abstract}

\section{Keywords}

Modes of Acquisition, Ownership, Private Property, State Territory, Territorial Sovereignty, Title to Territory

\section{Introduction}

In the $19^{\text {th }}$ century, when scholars of international law discussed "the rights of State territory" or a State's "rights of property," a persistent difference was the analogy between State territory and private property. Some, including Henry Wheaton and T.J. Lawrence, described State territory as territorial possessions and, quite candidly, identified it as State property. Others, such as John Westlake and Lassa Oppenheim, declared that State sovereignty over territory was emphatically not property. They preferred a strong distinction between sovereignty over and ownership of land-to little avail. By the end of the $19^{\text {th }}$ century, a growing number of legal scholars treated State territory as State property. Why? This essay undertakes a history of the concept of title in order to explain how State territory came to be called State property. 
In his seminal work of 1927, Private Law Sources and Analogies in International Law, Hersch Lauterpacht (1927: pp. 43f, 50, 91) argued that, because international lawyers so often discussed State "acquisition of territory" with the term "property," State possession of territory was the best example of a reasonable analogy drawn between international and private law. He found it reasonable to equate State territory and State property. In more recent decades, ICJ cases regarding territorial disputes-many of which arose with the emergence of new, postcolonial States-have directly raised questions of ownership and title, and frequently treat State territory as property.

In much of the literature within international law, writers slip from one position on State territory to the other, from the "acquisition of title to sovereignty over territory" to the "acquisition of title to territory" or simply "acquisition of territory." They use title to territory and title to territorial sovereignty interchangeably. Although many insist that "territorial title" refers to a title to sovereignty - that which grants a State its rights over and within the territory-they speak in an apparently condensed fashion of title to territory and describe it as a claim analogous to title to property in private law. Even Jennings (2017), who emphasized the pertinence of the term "title" to contemporary discussions of acquisition of territory in international law, follows this pattern (see also Starke, 1965-66; Menon, 1994; McHugo, 1998; Kohen, 2017).

This is not to accuse him and other scholars of a lack of rigor. Rather, it was understood in the $19^{\text {th }}$ century that a State had a good title to a piece of territory based on its long administration or its otherwise effective occupation of the land. Some types of acquisition of title, however, such as annexation or conquest, invited confusion insofar as it was not the sovereignty of the indigenous people that was being conquered or annexed, but their lands. Simply put, title to territory is quite like title to property. It's a simple passage from territorial sovereignty to modes of acquisition of territory, and then it's a matter of acquiring and holding territory. States seek to establish "roots or sources of title" through boundary treaties, boundary awards, and other legal devices that demonstrate having acquired good title to a territory (see Shaw, 2005; Shaw, 2006).

But some scholars of international law assert a more principled position. They disregard any relevance between private and international law and disdain the analogy between States and individuals. Judge Chagla famously argued in the Right of Passage Case (cited in Strauss, 2015: p. 41) that citizens and sovereign States are incommensurate. A sovereign state "can compel the owner of land to cede any right to neighboring owners" but the same is not true of territorial sovereigns, for such compulsion would contradict territorial sovereignty--"the one undisputed, well-established principle of international law." Similarly, Marcelo Kohen and Mamadou Hébié (2013) have noted the equivalence between ownership and sovereignty suggested by the ICJ but, like Westlake and Oppenheim, they would maintain a distinction between sovereignty and ownership, and they do not identify State territory with ownership of land. State territory is not State 
property; territory not a matter of possession or ownership, but an extension of sovereignty. As Mieke van der Linden (2014: p. 101) has suggested, "title to territory" is a "misconception," because it misinforms a relationship between sovereignty and property. Rigorously speaking, "title" refers to property rights within private law, and "territory" refers to sovereignty, a matter of public law.

In explaining these attitudes, Lauterpacht (1927: pp. 50, 71-79) pointed to $19^{\text {th }}$-century developments such as legal positivism, the absolutist view of the State, and related theories of the supremacy of the State. He noted that sovereignty to such scholars is a more exalted concept than possession or ownership, and thus more appropriate to a State. However, I do not think that the exalted nature of the State motivates recent writers such as Chagla, Kohen, or Hébié. Rather, they seek to uphold international law as a comprehensive system, which encourages the rigorous distinction between international and private (or municipal) law. Kohen (2013), for example, in a discussion of "original title," and Steven Ratner (1996), in an analysis of uti possidetis, demonstrate that concepts particular to international law are adequate to adjudicate title to sovereignty, without resorting to any analogy between territory and property. In a direct rebuttal of Lauterpacht's endorsement of the analogy between State territory and private property, Roger O'Keefe (2011) demonstrates that the international legal concept of "effectivités" is sufficient to display territorial sovereignty without recourse to title; he regrets that earlier scholars took recourse to the private law analogy of acquisition of immoveable property. ${ }^{1}$

Nonetheless, a seeming majority continue to use title to indicate claims to territory. International lawyers, international courts, arbitration tribunals and agreements acknowledge that a valid title to territory legalizes sovereign rights to that territory. Title designates both the source and the result of those rights (Van der Linden, 2014: p. 101f). Even though Kohen and Hébié describe this position as an "Anglo-American prejudice," such usage of title is widespread beyond the UK and USA. Even those who promote the "rigorous" approach to title have recourse to formulations such that "exclusive title to territory is proof that a State owns the territory;" or their enumerations of "modes of acquisition of territory" rely on the terminology of property ownership (Sharma, 1997: pp. 1-33). International law is marked by a widespread assumption that State territory is defined by a title that demonstrates State ownership of the territory. The divestment of Germany in the 1919 Treaty of Versailles (Part IV, Section 1, Article 119), for example, declared that "Germany renounces in favour of the Principal Allied and Associated Powers all her rights and titles over her overseas possessions." Those territories were German property, insofar as Germany held titles to those territories, and Germany thus could transfer them to another. State territory is State property.

What follows is a history of the concept of title in the law of nations and in-

${ }^{1}$ Giuseppe Nesi (2018: par. 11-12) succinctly defines "effectivite" as "the conduct of the administrative authorities proving the effective exercise of territorial jurisdiction in the region during the colonial period". 
ternational legal texts, a history marked by the distinction between dominion (possession or ownership) and imperium (sovereignty). The State itself emerges as owner of territory as opposed to a person such as a king, and State authority comes to extend over a territory, and the things and persons therein. Three problems drove the institutional shift that solidified in the $19^{\text {th }}$ century: prize law, which made the State an owner of property; the expansion of imperialism, which raised the question of title to colonial acquisitions; and the analogy between the State and the individual. With States identified as the sole "subjects" of international law, they were expected to behave like individuals. International arbitrations and ICJ casework subsequently normalized the use of State title to mark State ownership of territory as a form of property. Recent challenges to the status quo, however-to reassert aboriginal title to land, for example-may well fracture the bond between State and territory and produce a new understanding of State sovereignty.

\section{Title as a Right of Possession (Dominium)}

The paradigm for "title" in the $16^{\text {th }}$ through $18^{\text {th }}$ centuries was laid out with laudable clarity in the 1538 essay of Francisco de Vitoria, "De Indis." According to Vitoria (1991: pp. 234, 251, 258, 263, 277), a title is a ground, claim, reason or right for a particular action of possession and rule. So, when a man is entitled "King of Spain," that title indicates that he has the right to occupy and to rule Spain. The important condition on such a title is that it be "just": that it can be proved to be relevant and defended as legitimate. Accordingly, Vitoria (1991: pp. 251f, 264f) asserts that title is bound up in a set of powers called dominium (possession), which include, at a fundamental level, the personal rights of ownership over one's own body and possessions and, at higher levels, rights of jurisdiction in ecclesiastical or public affairs. Dominion and its relevant titles are visible in a hierarchy of ownership, from God to the Pope, to Kings and their vassals, down to the common man. ${ }^{2}$

This understanding of title persisted for at least two centuries, although the conceptual framework around title shifted considerably. Vitoria (1991: pp. 277-291) was keen to question "by what power we Christians were empowered to take possession" of the territory of the "Indian barbarians" of the New World. He judged that natural law did not recognize any right or title by discovery or by grant of the Pope, or because God had ordained the King of Spain to become Master of the World, or because of the heathen status of the Indians. Barbarian lands did not constitute things available to the first taker insofar as they belonged to no one (res nullius). Rather, the Indians rightfully possessed their own lands and their just title had to be respected. Vitoria did, however, hold the Indians guilty of having violated the Spaniards' natural rights to travel and to trade, which justified Spanish punishment, enslavement, and eventual rule of Indians' lands.

${ }^{2}$ For a helpful clarification of Vitoria's language, see Fitzmaurice, 2014: p 57f. 


\subsection{The Roman Model of Property}

By comparison, writers in the $17^{\text {th }}$ century embedded the concept of title in a Biblical and pseudo-historical description of the origins of civil society, the nation, and the State. Grotius, Hobbes, Locke, Pufendorf and others provide a familiar imagined history, one primary motive for which was to justify government by monarchy. Men naturally appropriated things belonging to no one, or res nullius, to their own use and thus to their personal ownership-food, clothing, and eventually land. Subsequently, as a group, they formed a society or nation and consented to mutually acknowledge the property of each. By going a step further and creating a State, they established laws to govern the ownership and transfer of property, and placed a sovereign at the head of the State to enforce the law. In his essay of 1605, The Free Sea, Grotius (2004: pp. 129, 176) enlisted Roman law to explain definitively the right or title to property: a general title to something includes both the object of possession and the legal justification for possession-an acknowledgment by statute, custom or order of the right to transfer one's own property. Grotius offered several examples-in a lawsuit, a judicial decision might grant title to the proper owner; or in warfare, a king might grant title to spoils of war to his subjects.

\subsection{Title as a Moral Claim}

Samuel Pufendorf (2005: p. 12 [\$I. i. xx.]), a generation later, explained that "Title" or "Right" is "that moral quality by which we justly obtain either the Government of Persons or the Possession of Things, or by the force of which we may claim somewhat as due to us." Hence, "titles" of rulers are those moral attributes applied for the distinction of persons, with reference to "their State and their Esteem." Although some titles-for example, "the most Serene, the most Eminent, the most Illustrious"-appear to give a degree of value and repute to a particular person, the title actually refers to the office or royal house: "the Thing itself" (2005: p. 10f [§I. i. xviii.]). One possesses a just title as king because one has inherited it from one's predecessors according to rules of succession. Like his contemporaries, Pufendorf linked monarchs to land on the basis of the Roman understanding of property.

\subsection{National Territories and Colonial Claims}

Yet the $17^{\text {th }}$ century was also the time when overseas imperialism began to produce conflicts among European powers. Colonial claims and settlements overlapped, and the powers decreed exclusive rights to trade or exclusive rights to waters elsewhere on the globe. Hence part of the concern with title in the $17^{\text {th }}$ century was immediately related to imperialism. Drawing directly from Vitoria, Grotius (2004: pp. xviii, 17-20, 312f) questioned the basis of Portugal's alleged rights to trade with, to navigate through, and to occupy foreign lands. He agreed with the analysis of Vitoria and asserted-in the context of Dutch trade rivalry with Portugal-that Portugal did not and could not possess any islands in the 
Indian Ocean because they were already owned by local peoples. Moreover, Portugal possessed no natural right to trade exclusively with local peoples; such a conditional right was conferred upon others solely by the authority of local peoples and their rulers. Nor could Portugal claim imperium or sovereign jurisdiction over islands and thereby restrict other States or powers from trading with them. The seas were the "common property" of all men, and all had a right to navigate through them and potentially to trade with peoples therein.

Grotius's rehearsal of the origin of property had as its subtext the occupation of land through long tenure, the construction of boundaries, and the State's authorization of personal property rights. This was an argument for immoveable property based on moveable property. Pufendorf (2005: pp. $394 f$ [IV. iv. vi.], 415 [IV. vi. xii.]) reiterated the argument, but with surprising inattention to questions of imperialism and colonialism. At one point he noted that the object of original acquisition must be res nullius, but was most concerned that possession accord with statutes and legal order. Hence, he famously defended the right of a slave owner to recover a fugitive slave, because the latter remained property, according to the law.

This neat understanding of title and ownership began to break down in $18^{\text {th }}$-century accounts of the law of nations. In the prominent works of Christian Wolff (1934: pp. 124-28 [\$248-249]) and Emer Vattel (2008: pp. 281-88 [II. $\$ 35-48]$ ), “Titles" are primarily those expressions of distinction that grant value and repute to particular rulers. Both writers followed the $17^{\text {th }}$ century authors' pseudo-history of the creation of society, nation, and State. Vattel explained that when a people formed themselves into a political society or nation, they had a "peculiar and exclusive right" to the country where they settled; this right comprehends both dominium and imperium-not only possession of the country and everything in it for the nation's use, but also the sovereign command over everyone and everything within the country, in order to regulate it well. Vattel (2008: p. 213f [I. \$203-205]) asserted, "The whole space over which a nation extends its government, becomes the seat of its jurisdiction, and is called its territory." To this territory and domain that the nation justly possesses, the nation has a "just title" (2008: p. 302 [II. \$80]). Wolff (1934: p. 50f [\$85-87]), by contrast, asserted that, when a society unites into a State, they "occupy the sovereignty of the territory." The difference between Vattel and Wolff on this point is apparently the earliest expression of the difference of opinion regarding State ownership of territory.

Overseas territories represented a somewhat different type of possession to both Wolff and Vattel. Each took up the justification for European possession of overseas territories, but dropped the usage of "title" in referring to those lands. Both asserted that Europeans could rightfully occupy only uninhabited territories and uncultivated places; Vattel stressed especially the need for careful settlement of a territory so as to avoid encroaching upon others' lands and creating conflict. Like Wolff, he encouraged fixed boundaries in order to promote har- 
mony among nations. That said, however, Vattel offered the now infamous justification for European colonization of the lands of "erratic nations" such as the "Indians" of the Americas. Because their primary occupation was hunting, they did not cultivate the land and hence did not possess it; they were socially unable to establish a proper country with sovereignty over a domain. Thus, Europeans might justly occupy such uncultivated places, but a "just title" to such colonial possession might take time to acquire. Long settlement afforded rights of possession, but Vattel recommended purchase of land for the sake of clear and certain title of ownership (see Vattel, 2008: pp. 215-17 [I. \$207-210], 308-10 [II. \$92-97]; Wolff, 1934: pp. 50 [\$85], 140-48 [\$274-291]; see also Nuzzo, 2017: p. 273f). ${ }^{3}$

\section{Title as a Territorial Right of Property}

In the $19^{\text {th }}$ century, the political subtext informing "international law" shifted, as the State took precedence before kings and "State title" to territory began to signify State ownership of territory-as exemplary of a State's "rights of property." There was no longer any need to justify the unique rule of monarchs; kings had accepted the independence of Switzerland and the Netherlands as republics in 1648 , and then the independence of the USA in the $18^{\text {th }}$ century. During the course of the French Revolution, a number of peoples had expressed their self-rule, either to reassert their independent Statehood, such as the Dutch and the Swiss, or to create an independent State, such as Poles, Saxons, and Norwegians, or to consolidate with the French Republic, such as French majorities in Corsica, Avignon, and Alsace (Kolla, 2017). Instead of the imaginary origin of society, nation, and State that we find in earlier writers, the $19^{\text {th }}$ century witnessed a new approach: International publicists began their books by asserting the State as the principle subject of international law and emphasized the State's sovereignty, such that each State is autonomous in both internal and external matters, and that all States are "equal in the eye of international law, whatever may be their relative power" (Wheaton, 1936: p. 44 [\$33]). American writers in particular encouraged this approach, because, after decades of interference by the British Navy with the USA's merchant fleet, the War of 1812 forced the UK to recognize the equality and sovereign rights of the USA. Likewise, after years of indifference or hostility on the part of the European powers to recognize former Spanish colonies as newly independent States, South American authorities such as Carlos Calvo were eager to assert State sovereignty (Becker Lorca, 2014: pp. 103-107).

\subsection{State Ownership: Moveable Property and Immoveable Territory.}

Alongside the promotion of the State, State "title" entered into international law

${ }^{3}$ Both Wolff and Vattel were informed by John Locke's theory of "First Taking" or "First Occupancy" - the idea that a man's application of labor to what he finds in nature makes it his property, and requires both working the land through one's labor and marking it as one's own through some enclosure that restricts others' access. See Locke, 1988: pp. 289-91 [II, 30-32]. 
regarding State ownership of property. This ensued initially through prize law-the body of rules that governs the seizure of enemy or neutral property on the high seas during war. European monarchs had long claimed that enemy ships and property seized as prize during war became the property of the King, and Grotius (2006: pp. 190-242) established as a principle of the law of nations that prize was justly seized in a just war. But a complication occurred with the 1681 Maritime Ordinance of Louis XIV, which decreed that, among other measures, enemy property on neutral ships could be seized as prize (see Wheaton, 1815: pp. 34-47; Wheaton, 1936: pp. 22f [\$15], 479-85 [\$443]). Prize law subsequently developed in the $19^{\text {th }}$ century as an effort to coordinate a uniform practice. When a national Navy or a privateer seized ships or cargo, they did so on behalf of a State, which then had the right to sell or otherwise alienate such “prize." Theodore Woolsey (1874: pp. 238-40 [\$140-141]), writing in 1860, noted that a State's title to prize began with the fact of seizure and only became a "complete title" when a competent court gave such sentence. In this analysis, the State acts as an individual owner of moveable property, and State "title" was informed by the Roman legal analysis of "title": title to objects required both possession and the legal justification for possession.

The critical change occurred when the State was considered as an owner of immoveable property-land, rivers, and coasts. Henry Wheaton (1936: p. 200 [\$161]; see also Hall, 1924: pp. 52f, 125; and Fiore, 1918: p. 415f [\$1034-1037]), in his classic Elements of International Law of 1836, extended his understanding of title in prize and moveable property to immoveable territory: "The exclusive right of every independent State to its territory and other property is founded upon the title originally acquired by occupancy, conquest, or cession and subsequently confirmed by the presumption arising from the lapse of time, or by treaties and other compacts with foreign States." Writing in 1855, Robert Phillimore (1857: vol. III, pp. 451f, 469) noted that in order to rightly possess conquered territory, a State must receive from the subdued people a formal acknowledgement that they are conceding or yielding the territory to the conqueror. Like moveable property, all forms of immoveable property required for proper title both possession and its justification.

\section{2. "Modes of Acquisition" of Title to State Territory}

To more elaborately explain the State's control of territory as title to property, $19^{\text {th }}$-century writers began to enumerate "modes of acquisition" of title to territory. There were two primary modes. Title was either "derivative," such that the territory already belonged to one people who transferred it to another, or "original" (a.k.a. "primitive"), such that the territory was newly acquired. Derivative title arises mainly from conquest or cession; one either forcibly takes the land or obtains an agreement that its owner has ceded it. Original title includes prescription, accretion and, most commonly, occupation. Prescription is what Wheaton (1936: pp. 200-202 [\$161-165]) above noted to be "presumption arising from the 
lapse of time"; accretion is the natural capacity of water and land to shift and create new land (see also Twiss, 1884: pp. 195-227 [\$116-139]; Lawrence, 1895: pp. 143-152 [\$92-94], 156-60 [\$97-100]; Hall, 1924: p. 125; Fiore, 1918: pp. 422-435 [\$1055-1102]; and Oppenheim, 1920: vol. I, pp. 372-403 [\$209-243]).

"Title by occupation" became the dominant mode of acquisition in the $19^{\text {th }}$ century, as a result of Western colonialism. Attitudes toward indigenous peoples changed, so that territories which once appeared unavailable were newly available for the taking. Vattel's analysis of "erratic nations" was widely reiterated as justification for the seizure of lands used by hunter-gatherers, nomadic groups, and any people deemed "primitive." Such groups did not properly possess the land as settled agricultural societies might. Moreover, as Antony Anghie (2004) has recounted, the European notion of a society of nations, membership in which depended upon a level of European civilization, served to exclude all indigenous nations and States in Africa, Asia, Australia, and the Americas. Exceptions were few-Egypt, Ethiopia, China, and Japan, for example, were deemed "semi-civilized" because they had States and could not be easily occupied. As a result, those lands were forced to submit to conditions of extraterritorial privileges for Europeans when they sojourned or undertook commerce there.

Travers Twiss, Henry Sumner Maine, and others noted that res nullius in reality applied only to deserts, distant islands, and other vacant territory - lands that remained uninhabited for good reason. Twiss (1884: pp. 22-24 [\$135]) found it acceptable that Europeans and the USA extinguished "Indian title of occupancy" through purchase or conquest and asserted instead "territorial title of Sovereignty." Conquest was a respectable practice, and settlement was the best sign of occupation and created a perfect and exclusive title. Maine (1890: pp. 59-61) concurred, noting that a State has a right to occupy unappropriated territory, but he did admit that the nature of "unappropriated" was in dispute. Lecturing in 1888 , he soberly noted the reality of the situation. Yes, native peoples held what may be called "native indigenous title" to their lands, and might give it away with their consent, but some authorities, such as the USA, had categorically eliminated "savage nations" as capable of holding territorial title, and others, such as the East India Company or Chancellor Bismarck, had simply annexed it. A "good international title," Maine (1890: pp. 68, 71-75) acknowledged, typically depended upon ratification by others.

Lawrence, by contrast, disagreed with Vattel and his followers, in a way that significantly foresaw later developments. Lawrence (1895: pp. 145f [\$92], 154f [\$96], 161-165 [\$101-103]) allowed that a nomadic tribe, however civilized and organized, could indeed be considered a State. He asserted, however, that the confusion generated by the "scramble for Africa" demonstrated that native peoples did not have a legal claim but a moral claim to their territory. European powers may justly occupy and settle such lands, but they are required to uphold the moral claims of the natives and to protect them accordingly. The European power thus may acquire a title to a colonial territory, but such territories are 
better understood as protectorates or spheres of influence. ${ }^{4}$ This view would become international policy in the 1920s with the League of Nations.

\subsection{The Analogy between State and Individual}

Twiss (1884: p. 191 [\$119]), Maine (1890: p. 56f), and Lawrence (1895: p. 159 [\$99]) asserted an analogy between the nation or State and the individual-as Twiss put it, each has a right to possess both the fruit of the earth and the soil which produces it. However, where they noted the origin of this analogy in feudalism and declared that the sovereign State had replaced the sovereign monarch, John Westlake and Lassa Oppenheim objected strongly to that analysis. In part, their objection follows from their rejection of the historical origins of the analogy in feudalism-a former and rightly forsaken time when lords possessed land. They believed that something new and modern had taken place since the 1400s, as Europeans spread out around the globe, making geographical discoveries and claims upon new lands. As a result, Westlake declared, Europeans faced the question as to how to acquire territories in these new countries, which are typically lands inhabited by natives whose communities have not become States. European occupation, he concluded, is best described as the practice of a civilized State extending its sovereignty into a new area. Westlake (1894: pp. 129-135) and Oppenheim (1920: vol. I, p. 305f [\$168]) opposed the idea that a State owns territory in the same way that an individual owns land. Rather, Westlake wrote of "title to territorial sovereignty" and Oppenheim the "territory subjected to the sovereignty of the State." Both insisted that State territory is not a matter of dominium - it is not property; it is not something owned. Rather, the State has imperium or sovereignty over its territory, which includes all land, persons, and things within the territory.

This understanding of imperium expands the concept of sovereignty in a novel direction. Where sovereignty was once understood as authority over persons, Westlake, Oppenheim, and others would extend sovereignty to the relationship that the State bears to its territory. Such an analysis narrows that of Twiss (1884: pp. 193f, $230[\$ 115,143])$, who asserted that the State possesses its territory as a right of property (dominium), and that the State also holds rights of empire (imperium) as jurisdiction or sovereign control over everything and everyone within the territory. Westlake and Oppenheim would instead limit the authorizing principle to sovereignty, which provides a sufficient explanation without recourse to dominium. However, like his fellow international lawyers, when Oppenheim (1920: vol. I, pp. 372-74 [\$209-210]) turned to a discussion of "modes of acquiring State territory," he found the analogy between the State and individual as property owners entirely apt, and disregarded his earlier theoretical objection. He could not link sovereignty and acquisition without passing through dominium, or possession; and his "modes of acquiring State territory" remain conventionally what others call "modes of acquisition of title to territory."

"John Westlake (1894: p. 145) too described natives as having a "moral title" to land. 


\subsection{The State's Rights of Property: Eminent Domain}

A basis for these disagreements over the analogy between State and individual and the relationship of State to territory becomes clearer in works of the 1880s by William E. Hall and Pasquale Fiore. The key is the concept of eminent domain, which figured in earlier accounts of law that justified the rule of monarchs. Eminent domain was a prominent concept in the $17^{\text {th }}$ and $18^{\text {th }}$ centuries, often paired with taxation in enumerations of the set of sovereign rights. Grotius, Pufendorf, Wolff and Vattel all agreed that the sovereign power possessed the right to take property for the benefit of the social unit. The right was created by society, insofar as it constituted itself by aggregating the territory of all private lands, and the right was passed on to the sovereign, who could act out of necessity, "the exigencies of the State," or the public welfare. But the State is advised to "temper its right with rules of equity," as their contemporary Burlamaqui (2006: p. 438 [III.v.xxiv-xxviii]) put it, or to "make good the damage to those who lose their property," according to Grotius (1925: pp. 385 [II.xiv.vii], 807 [III.xx.vii]). The State should compensate the injured property owner for his losses (see Pufendorf, 2006: pp. 44, 47; Wolff, 1934: p. 60f [\$102-103]; and Vattel, 2008: p. $232 \mathrm{f}$ [I.xx. \$44]).

Eminent domain dropped out of accounts of international law, as a consequence of its shift away from the legitimacy of monarchical government. It reappears in the 1880s, now in the context of the State's "rights of property." Like Westlake and Oppenheim, Hall and Fiore agree that a State is not like an individual property owner, because the State's relation to its territory is best described as the State's extension of its sovereignty over territory. They acknowledge the State's supreme right of eminent domain, derived from its sovereignty. However, they both admit that when the State exercises such a right over its territory, that action necessarily resembles legal possession of property. Compensation for seizure of private property under eminent domain requires fiduciary transactions based on calculations of value; and a defense of territorial possession requires a defense of title. Fiore (1918: p. 415f [\$1034-1037]) observes that such actions, even though they follow from sovereignty, must be exercised through the right of dominium (possession). Hall (1924: p. 52f [\$9]) notes the theoretical dilemma, and concludes that the "proprietary character" of a State's possessions follows logically from the fact that the State is "the only recognised legal person" and must assert its territorial rights in international law as property rights. "A right of property...in order to possess international value, must be asserted by the State as a right belonging to itself." Because the State is a legal person with rights, the State must act as the owner of its territory (see also Bluntschli, 1895: pp. 253-55).

By the end of the $19^{\text {th }}$ century, then, many writers on international law were in agreement that the State possesses territory in the same way that a person owns land-through a valid title defined by both the object of possession and the legal justification for possession. Based on its title, the State has dominion over its ter- 
ritory, and sovereignty over everything and everyone within that territory. As a mark of this expansion of sovereignty as a territorial principle, Twiss (1884: p. 260 [\$159]) noted that "territorial sovereignty" (sovereignty over territory) had come to take precedence over "personal sovereignty" (sovereignty over persons) because a State cannot enforce its laws over its subject whilst he is abroad. State sovereignty had become primarily territorial sovereignty. ${ }^{5}$ Accordingly, State territory was treated routinely as State property.

\section{The Normalization of State Title}

How was State title normalized within the international legal framework under formation? Developments in both private property law and colonial possessions help to explain this process, particularly as the number of boundary disputes grew in the $19^{\text {th }}$ century. But before delving into those matters, we must note the difference between continental European and UK-especially English-law, which provided the context for these legal developments. On the one hand, because the UK dominated colonization and followed UK precedent in colonial disputes with other States and, on the other hand, because the creation of both the International Law Association and the Institut de Droit International in 1873 encouraged a common approach among international lawyers, diplomats, and political leaders, continental and UK approaches to State territory and property began to converge by the end of the century.

\subsection{Approaches to Property: English Common Law vs. Legal Codification}

The development of codification among continental powers in the $19^{\text {th }}$ century created a trajectory different from that of the common law of the UK. Continental authorities strongly distinguished sovereignty from property, because sovereignty is treated in the public law of constitutions and property is managed through the private law of civil codes. Bluntschli (1895: p. 243f), for example, reiterated the principle through the many editions of his Allgemeine staatslehre in the last quarter of the $19^{\text {th }}$ century. The law concerning property asserts a fundamental difference between possession and ownership. Possession is the physical fact of holding an object; ownership is an absolute right vested in the individual, an all-comprehensive right and power over a thing. Ownership is thus the legal dimension of property-one may possess something but the right of ownership follows from the legal sanction to transfer a possessed property. Title is accordingly a regulatory concept underpinning the property institution-the seal of ownership. Although possession is often accompanied by the belief that the possessor is the owner, possession and ownership do not necessarily coincide (Castellino \& Allen, 2003: pp. 30-39; DiStefano, 2006; Van der Linden, 2014: pp. 27-37).

The common law of the UK differed significantly. Because of its feudal notion

${ }^{5}$ The idea has since then been normalized by international lawyers; see Van der Linden, 2014: p. 49. 
that the monarch is the owner of all land, ownership in the UK gave rise to the doctrines of tenures and estates, such that a tenant owns a tenure or estate in land rather than the land itself. Land transfers in the UK, hence, were not a matter of dominium or ownership, but rights of possession. Common law is more concerned with the different kinds of possession by private individuals (Anderson, 2010; Gray \& Gray, 1998).

Coincidentally, at the same time that title appeared in treatises on international law, title to land began to feature in public policy discussions during the last third of the $19^{\text {th }}$ century. In England, the largely middle-class movement for "free trade in land" sought to treat land as a form of wealth and to make land sales as simple as a sale of stocks. This effort to create a property market would remove land from its longstanding moral context of "inheritance" and create a public and simplified system for title registration. Where land transactions had long required an extensive title investigation on the part of a conveyancer, which clarified "original" grants of ownership in distinction to multiple layers of leaseholds, title registration promised to reduce the duration of and fees required for a land sale. An initial step was taken with the Land Transfer Act of 1875, which allowed for voluntary registration of land title, but a mandatory and comprehensive system of title registration in England was not enacted until 1925 (Fitz-Gibbon, 2018: pp. 120-137).

Meanwhile, advocates of title registration took their efforts to British colonies, beginning with Ireland, New Zealand, and South Australia. South Australia proved to be the easiest environment for title registration, because the principle of terra nullius ("no man's land"), which underlay Crown grants of land to private persons there, created a clean slate for assigning ownership (Fitz-Gibbon, 2018: pp. 137-145). Although it is beyond the interests of this essay, the British colonial situation was complicated by the UK conception of sovereignty, which informed royal ownership of the colony (dominium), as well as "titles" and "estates" conferred upon royal subjects. Eventually, in order to regulate "landowners"-i.e., possessors of land-in British colonies, the Foreign Jurisdiction Act of 1890 and bodies of case law provided legislation and juridical guidance (Johnston, 1973; Van der Linden, 2014: pp. 147-152, 159, 162). Although the common law rule that "possession is proof of title" came to facilitate colonial occupations of land, in recent decades in former UK colonies, it has become the object of multiple legal cases concerning aboriginal or indigenous title-a point to which we return.

\subsection{State Property: International Leaseholds}

Attention to title arose among States internationally, with what Michael Strauss (2015: p. 70) has identified as a surge of leasing activity after 1878. An international leasehold is simply the renting of foreign territory in accord with the legal principle that a State's sovereignty over its territory includes the right to temporarily alienate its territory. Yet, as Fiore and Hall had acknowledged, as a con- 
tract between two States for the benefit of the lessee State, a typical international lease has the character of a private property transaction; the lease agreement depends on the lessor having proper title to the territory in question. The surge in leaseholds that began in 1878 was initiated by the UK and the declining Ottoman Empire, which was willing to lease what it increasingly could not defend. The UK leased Cyprus; Austria-Hungary leased Bosnia and Herzegovina. The UK leased the Khyber and Michmi Passes from Afghanistan in 1879, and Chile leased provinces from Peru in 1883. Apart from conquests, the European powers leased many territories in eastern Africa in the 1880s and then turned to western Africa in the 1890s. Their goal was to secure land for coaling stations, supply depots, and storage facilities-all in the service of promoting national maritime trade (Strauss, 2015: pp. 70-80). Another flurry of leases occurred in the wake of China's 1895 defeat in the Sino-Japanese War: Russia leased parts of the Liaodong peninsula in order to have a naval station close to its eastern frontier; the UK leased Weihaiwei for a naval base in the proximity of Beijing, Korea, and Japan; and France leased part of Guangzhou Bay for a naval base between Chinese ports and its colony of Indochina (Verzijl, 1970: pp. 400-404; Young, 1931: pp. 97-104).

\subsection{State Property: Boundary Disputes}

In addition to leasing activity in the historical record during the $19^{\text {th }}$ century, "title" began to appear in international disputes in order to identify property ownership. So, for example, when gold was discovered in the 1850s along the Orinoco River-decidedly within the territory of Venezuela but bordering UK claims in British Guiana-a boundary disagreement between the two States arose in 1857. The border was imprecise, because it had not been fully surveyed and especially because the physical British landmarks had been removed at the request of the Venezuelan government in 1842. Although Venezuela had claimed the Orinoco delta in 1830, Point Barima on its southeastern cusp was arguably in British territory, because the Barima River flowed through British Guiana. UK officials expressed their concerns to the Colonial Office in the late summer of 1857. They admitted that Point Barima held minimal commercial and strategic value; it would never compete with the superior facilities at Trinidad. But they felt strongly that the UK maintain its claims in the area, for three reasons. First, a third party could move into the area, particularly since the Venezuelan government had granted gold concessions to the USA and France. Second, in the event of some future conflict, Venezuela might not grant the UK access to the Orinoco or worse, allow a hostile power access. And third, the discovery of gold might well invite all manner of gold seekers to stray into British territory, creating social problems or potential labor shortages, if indentured coolies and Portuguese workers slipped away from British settlements into the gold fields. Simply put, this unpromising piece of land had the potential to become useful, profitable, and troublesome (Colonial Office: file 884/1). 
UK officials were keen to proceed amicably with Venezuela, so they carefully reviewed the history of Dutch and English claims to the Barima River. In the absence of strong evidence for either claim, UK officials offered an alternative analysis of land titles in terms of "the practical sway and sovereignty of a State" over tracts of land. Did Venezuela's "right" to the land require a "much clearer technical title" or not? Because the land was "wilderness" neither settled nor cultivated, had not been fully surveyed, and all traces of past boundary markers removed, UK officials argued that no proper titles could be ascertained. Hence, they framed the question in terms of "natural rights" or "rights of situation and circumstance." Venezuela might argue that it had a natural right to Point Bari$\mathrm{ma}$; it was attached to a Venezuelan possession at the mouth of a navigable river, the Orinoco, which gave "constructive title" to all land through which the river flowed until it met with some other more positive title. By contrast, UK officials argued, possession of the territory through which a river flows-the Barima-implies a "title nisi" to the mouth of that river. (A "title nisi" is a title that stands unless an adversely effected party shows cause as to why the title should be withdrawn.) The UK owned the territory surrounding the Barima River and hence it rightly claimed Point Barima, no matter how close it was to the Orinoco delta (Colonial Office: file 884/1). Venezuela acquiesced in this perhaps sophistic UK argument, but neither party was strongly motivated to alter the ambiguous status quo in $1857 .{ }^{6}$

\subsection{State Property: International Arbitrations}

Arbitration cases in the last third of the $19^{\text {th }}$ and first third of the $20^{\text {th }}$ centuries attest to the growing reliance upon title. Title appeared in the 1870 arbitration report of the U.S. President Grant regarding the Bulama Island dispute between the UK and Portugal: In rejecting both UK and Portuguese reliance on the indigenous peoples' claims to the Island, Grant asserted that, "This fact [that the island has not been inhabited by either the Bissagoo or the Biafares since 1699] seems to dispose of all titles on either side derived from deeds, cessions, declarations, or other acts of the native tribes" (Arbitral Award of the President of the United States, Regarding the Dispute between Portugal and the United Kingdom about the Sovereignty over the Island of Bulama ... Decision of 21 April 1870). The Arbitration Treaty of 1897, between Venezuela and the UK-following from the case of Point Barima just discussed-included a "Rule No. 1" which provided that "Adverse holding or prescription during a period of fifty years shall make a good title. The arbitrators may deem exclusive political control of a district, as well as actual settlement thereof, sufficient to constitute adverse holding or to make title by prescription" (Award of the Tribunal of Arbitration ... regarding the Boundary between the Colony of British Guiana and the United States of Venezuela, Decision of 3 October 1899, p. 335).

${ }^{6}$ The boundary was submitted to an Arbitration Tribunal in 1897, which defined an explicit border in 1899; see "Award of the Tribunal of Arbitration ... regarding the Boundary between the Colony of British Guiana and the United States of Venezuela, Decision of 3 October 1899.” 
One of the most interesting cases is that which became the 1930 Honduras Borders Arbitration, involving Honduras and Guatemala. Among other goals, the arbitration tribunal sought to trace the ownership of territory belonging to the King of Spain, through the administrative control which He granted to various civil and ecclesiastical authorities, to possession on the part of contemporary States. A key argument was that the King's title created administrative authorities, which subsequently became colonial and State authorities ("Honduras Borders," 1949: p. 1324). So, for example, in their examination of the Valley of Copan, the arbitration tribunal noted a property which the church had taken in the 1700s, and which had been considered to be within the "Gracias a Dios of Honduras" ("Honduras Borders," 1949: p. 1344). Only royal authority could have created such a grant of land and granted its jurisdiction to the church. To the arbitration tribunal, this was evidence that the assertion of civil authority in such a land grant was based on the King's possession of title to the land, and that the King's grant of ecclesiastical jurisdiction had been transferred to Honduras. Hence, the long exercise and recognition of Honduras' civil jurisdiction in the Valley justified its claim to the title thereto ("Honduras Borders," 1949: pp. 1345-47).

These examples make clear that, in the practice of international law in the $19^{\text {th }}$ century, title was increasingly invoked as the legal confirmation of State ownership of territory. Property and possession might be assumed on the part of a State, but if that claim were challenged or overturned, a legal resolution depended upon demonstration of a good or proper title to the territory.

\section{Title in Postcolonial Jurisprudence}

That the rigorous differentiation of sovereignty and ownership merges with the treatment of territory as property is due in part to the fact that at issue in territorial or border disputes is an object, land. One of the disputing States must demonstrate sovereignty over the territory and the more straightforward strategy of doing so is to demonstrate ownership. Although O'Keefe has shown that one can in fact substantiate sovereignty by effective occupation through a defense of effectivités, title is a more common strategy. In a representative case, such as the Island of Palmas Case or the Honduras Borders arbitration, a State plaintiff claims the "title" to some territory and argues that it has the right to possess that territory rather than the State which does possess it. The plaintiff must demonstrate having State title to the territory. As the legal mark of ownership, title thus secures a legal remedy in a dispute over such a territory (Sharma, 1997: pp. 188-190, 199f; Jennings, 2017: pp. 18, 104; "Honduras Borders," 1949: p. 1323).

Giovanni DiStefano (2006: p. 1045) recommends this use of title and praises ICJ case law for its emphasis upon title in recent territorial and border disputes. Insofar as State territory is that territorial space within which a State exercises its sovereignty, title serves both to confirm the "root of a right" and to document "that which establishes and proves the existence of a right." Just as title confirms 
the right of property in private law, so too it confirms the rights of sovereignty within a territory in international law. DiStefano (2006: pp. 1042, 1048) faults "the so-called theory" of modes of acquisition for "its normative and actual inadequacy to explain and found the acquisition and loss of territory," and insists that title is a much clearer and more effective concept, because it has to do with a State's legal right to territory. He is "convinced that a rigorous application of legal title ... could be material in understanding and resolving territorial disputes."

\subsection{ICJ Reversals of Colonial Claims}

But title may be losing the privileged place it has held. The ICJ has made a number of momentous judgments in recent decades that overturn lingering colonial arrangements, as the court has confirmed the original rights and titles of indigenous peoples. In the celebrated Isle of Palmas Case (1928), the court confirmed effective occupation of terra nullius in order to demonstrate the legitimacy of a colonial claim to territory. Apart from the controversial effort to adjudicate exactly what quantity of what kind of administration counted as "effective occupation," the concept of terra nullius categorically nullified any and all indigenous occupation of seized territories as well as the binding force of all international agreements with native chiefs. It is this understanding that has been overturned in recent decades. Although the Island of Palmas Case dismissed questions of territorial control or "original title" on the part of native chiefs "not recognized as members of the community of nations" and acknowledged that the Netherlands had acquired the island as terra nullius, the ICJ, in the 1975 Western Sahara Case, negated the identification of Western Sahara as terra nullius and affirmed the presence of "peoples having a social and political organization." Similarly, the 2002 Cameroon v. Nigeria Case affirmed that treaties with native chiefs are proof of the legal standing of indigenous peoples (Servant-Le Priol, 2015: p. 59f; Huh, 2015: 716). Indigenous communities now may reassert their right and title to a territory. Charlotte Servant-Le Priol (2015: pp. 61-64) notes that indigenous occupation is now a legitimate mode of territorial acquisition, because neither effective occupation of terra nullius nor conquest are valid, and cession would legitimize the territorial sovereignty of indigenous people. She suspects that we may be returning to legal ideas of $16^{\text {th }}$ and $17^{\text {th }}$ centuries, insofar as we are granting legal personality to indigenous communities and acknowledging their rights to their homelands.

Is a right to a homeland the same as a title to territory? In recent decades, territory has undergone significant interrogation at the hands of geographers, who argue that territory should be seen no longer as a "thing" but as a "relationship" or "performance." Whether their work is described as "critical geography," the "sociology of territory," the "genealogy of territory," or "law and movement," these scholars locate territory within a network of socio-technical practices, which include governmentality, jurisdiction, property rights, boundaries, the self-determination of identity, and more (see Brighenti, 2006; Brighenti, 
2010; Blomley, 2016; Elden, 2013; Painter, 2010). Especially interesting is the work of Nicholas Blomley (2019), whose notion of "territorialization of property" demonstrates how property is treated as territory: bounded, surveyed, occupied and, with the sanction of law, owned. In effect, private property and State territory are twins, constructed together in Europe's early modern period. As a State has an exclusive claim to its territory, so a private owner has exclusive rights on his property.

\subsection{Upholding Aboriginal Title}

The question is, what consequences might a redefinition of territory have for international law and the concept of title to territory? Decisions in the Mabo $v$. Queensland Case (Australia, 1992) and Calder v. Attorney-General of British Columbia Case (Canada, 1973) have altered the relationships between the Crowns of Australia and Canada and their respective aboriginal peoples. Where, in the $18^{\text {th }}$ and $19^{\text {th }}$ centuries, the common law rule that "possession is proof of title" served to disestablish indigenous communities, these recent cases have distinguished territory from property and ownership (McNeil, 2019: pp. 163, 187; Reynolds, 1996: pp. ix-15). Instead of an absolute bond between State and territory, as an exclusive State claim to territory, something else is emerging.

In Canada, for example, the Crown court recognizes the rights of both the State of Canada and multiple indigenous nations in land once comfortably the exclusive and sovereign domain of Canada. The Court upholds those indigenous rights granted by treaties in earlier centuries and "un-ceded Indigenous interests in the land"-yet Canada struggles against this "reconciliation." At the same time that it acknowledges indigenous rights (or title) and opens the door to multiple sources of rights upon the land, the Canadian Crown insists that those indigenous nations recognize the sovereignty of Canada (Asch, 2002; Slatterly, 2007). Accordingly, Nicholas Blomley (2015: p. 169) asks, "how will the First Nation collectively hold its land?" Canada has proposed a new set of treaties with First Nations, which seek to "reconcile Crown sovereignty and title with un-extinguished aboriginal title." One of Canada's recent strategies has been "fee simple," a form of "freehold Estate" under Common Law that would replace the perhaps messy concept of "Aboriginal title" with "a clear and certain Entitlement” (Blomley, 2015: p. 171; see also Slatterly, 2007: pp. 268-279). Fee simple would treat indigenous interests in the land as a freehold estate, capable of being inherited and without any restrictions as to who may inherit. Fee simple would represent a legal burden on the title of the Crown. The problem with this proposed solution is that the collective nature of Aboriginal title would be reduced to individual property ownership, for the First Nation would allocate its collective fee simple estate among Nation members as individuals. Blomley (2015: p. 173) argues that

The treaty process attempts to bracket the very origin of Aboriginal title, with the Crown beginning from the assumption that a First Nation has 
some legitimate interest in its traditional territory, and that title need not be proven. However, some form of legible property relationship to its treaty lands must be crafted. This requires that the First Nation enter the space of the common law. To do so is to abandon the world of ambiguity, and enter the domain of legibility and clarity, predicated (of course) on "certainty".

In other words, "First Nations and their property interests are to be understood as subject to Canadian sovereignty and the common law, not placed outside it" (Blomley, 2015: p. 174).

Andrea Brighenti (2006: p. 75f) offers an insight that may be helpful to international law. Territory naturalizes the ownership of land, in the manner of property, but territory and property differ in one significant way: Territory is not so much a matter of exclusive enjoyment of certain goods as it is a matter of social relations, based on the State's dominant authority and enforced through its jurisdiction. Territorial title is thus a mark of sovereignty and, as the case of Canada demonstrates, the land may be shared and multiple parties may have rights to it, but the sovereign State prefers that one authority and one jurisdiction dominate.

\section{Conclusion}

This article demonstrates that scholars such as Grotius and Vattel in earlier centuries, who wrote under the rubric of "law of nations," validated royal claims to personal holdings and conquered territory overseas. As the State displaced the monarch, and the $19^{\text {th }}$ century turned to the rubric of "international law," sovereignty became territorial and the State became an owner of territory. The comparison drawn between international and private law encouraged the treatment of State territory as State property, and title began to indicate State ownership of its territory. Eminent domain, and international leaseholds, boundary disputes, and arbitrations established precedents for the use of "State title" as a claim to territory as property.

However, disagreements over the appropriateness of the analogy between international and private law continue to raise the question as to whether or not a State owns territory in the same manner as an individual owns private property. At the same time, recent postcolonial legal judgments, in both the ICJ and national courts, have questioned colonial State claims to indigenous lands and seek to return lands to their indigenous claimants, whose "Aboriginal title" predates European colonialism. This development may well undermine the tidy relationship between the State and its sovereign territory.

We may indeed be returning to legal ideas of the $16^{\text {th }}$ and $17^{\text {th }}$ centuries, insofar as we valorize sovereignty as the absolute power and authority of the ruler, no longer a monarch but the State. Given that "sovereign states are the only entities with enforceable power in international society," Sookyeon Huh (2015: p. 725 ) urges us to come up with a "rationale or legitimizing foundation for territorial sovereignty" in order to explain "why some kinds of territorial control can 
be recognized as vesting sovereignty." Given the general commitment to an international order of States, title and property may be shared, but must sovereignty remain unitary and absolute?

\section{Acknowledgements}

The Max-Planck-Institut für ausländisches öffentliches Recht und Völkerrecht, Heidelberg, generously supported the research of this article. It is a pleasure to thank Directors Anne Peters and Armin von Bogdandy for their counsel, and I remain grateful to Richard Dören for assistance and Friederike Kuntz for advice with an earlier draft of this new project.

\section{Conflicts of Interest}

The author declares no conflicts of interest regarding the publication of this paper.

\section{References}

Anderson, S. (2010). Property. In The Oxford History of the Laws of England, Vol. 12, 1820-1914, Private Law (pp. 1-294). Oxford: Oxford University Press.

Anghie, A. (2004). Imperialism, Sovereignty, and the Making of International Law. Cambridge: Cambridge University Press. https://doi.org/10.1017/CBO9780511614262

Arbitral Award of the President of the United States, Regarding the Dispute between Portugal and the United Kingdom about the Sovereignty over the Island of Bulama ... Decision of 21 April 1870. (2007) In United Nations, Reports of International Arbitral Awards, 28, 131-139.

Asch, M. (2002). From Terra Nullius to Affirmation: Reconciling Aboriginal Rights with the Canadian Constitution. Canadian Journal of Law and Society, 17, 23-40. https://doi.org/10.1017/S0829320100007237

Award of the Tribunal of Arbitration ... Regarding the Boundary between the Colony of British Guiana and the United States of Venezuela, Decision of 3 October 1899. (2007) In United Nations, Reports of International Arbitral Awards, 28, 331-339.

Becker Lorca, A. (2014). Mestizo International Law: A Global Intellectual History 1842 -1933. Cambridge: Cambridge University Press. https://doi.org/10.1017/CBO9781139015424

Blomley, N. (2015). The Ties That Blind: Making Fee Simple in the British Columbia Treaty Process. Transactions of the Institute of British Geographers, 40, 168-179. https://doi.org/10.1111/tran.12058

Blomley, N. (2016). The Territory of Property. Progress in Human Geography, 40, 593-609. https://doi.org/10.1177/0309132515596380

Blomley, N. (2019). The Territorialization of Property in Land: Space, Power and Practice. Territory, Politics, Governance, 7, 233-249. https://doi.org/10.1080/21622671.2017.1359107

Bluntschli, J. K. (1895). The Theory of the State (2nd ed., Trans. from 6th German ed.). Cambridge: Cambridge University Press.

Brighenti, A. (2006). On Territory as Relationship and Law as Territory. Canadian Journal of Law and Society, 21, 65-86. https://doi.org/10.1017/S0829320100008954 
Brighenti, A. M. (2010). Lines, Barred Lines: Movement, Territory, and the Law. International Journal of Law in Context, 6, 217-227. https://doi.org/10.1017/S1744552310000121

Burlamaqui, J.-J. (2006). The Principles of Natural and Politic Law (Tr. T. Nugent, Ed. P. Korkman). Indianapolis, IN: Liberty Fund.

Castellino, J., \& Allen, S. (2003). Title to Territory in International Law: A Temporal Analysis. Aldershot: Ashgate.

Colonial Office. UK, The National Archives, Kew.

DiStefano, G. (2006). The Conceptualization (Construction) of Territorial Title in the Light of the International Court of Justice Case Law. Leiden Journal of International Law, 19, 1041-1075. https://doi.org/10.1017/S0922156506003748

Elden, S. (2013). The Birth of Territory. Chicago, IL: University of Chicago Press. https://doi.org/10.7208/chicago/9780226041285.001.0001

Fiore, P. (1918). International Law Codified and Its Legal Sanction [1889] (Tr. from the 5th Italian ed., by E.M. Borchard). New York: Baker, Voorhis, \& Co.

Fitz-Gibbon, D. (2018). Marketable Values: Inventing the Property Market in Modern Britain. Chicago, IL: University of Chicago Press. https://doi.org/10.7208/chicago/9780226584478.001.0001

Fitzmaurice, A. (2014). Sovereignty, Property and Empire, 1500-2000. Cambridge: Cambridge University Press. https://doi.org/10.1017/CBO9781139924306

Gray, K., \& Gray, S. F. (1998). The Idea of Property in Land. In S. Bright, \& J. Dewar (Eds.), Land Law: Themes and Perspectives (pp. 16-51). Oxford: Oxford University Press.

Grotius, H. (1925). De Juri Belli ac Paci Libri Tres (Tr. Francis W. Kelsey). Oxford: Clarendon; London: Humphrey Milford.

Grotius, H. (2004). The Free Sea (ed. D. Armitage). Indianapolis, IN: Liberty Fund.

Grotius, H. (2006). Commentary on the Law of Prize and Booty (ed. M.J. van Ittersum). Indianapolis, IN: Liberty Fund.

Hall, W. E. (1924). A Treatise on International Law [1880] (8th ed.). Oxford: Clarendon.

Honduras Borders (1949). In United Nations, Reports of International Arbitral Awards, $2,1307-1366$

Huh, S. (2015). Title to Territory in the Post-Colonial Era: Original title and Terra Nullius in the ICJ Judgments on Cases Concerning Ligitan/Sipadan (2002) and Pedra Branca (2008). European Journal of International Law, 26, 709-725. https://doi.org/10.1093/ejil/chv036

Jennings, R. Y. (2017). The Acquisition of Territory in International Law. Manchester: Manchester University Press.

Johnston, W. R. (1973). Sovereignty and Protection: A Study of British Jurisdictional Imperialism in the Late Nineteenth Century. Durham: Duke University Press.

Kohen, M. G. (2013). Original Title in the Light of the ICJ Judgment on Sovereignty over Pedra Branca/Pulau Batu Puteh, Middle Rocks and South Ledge. Journal of the History of International Law, 15, 151-171. https://doi.org/10.1163/15718050-12340009

Kohen, M. G. (2017). New Introduction. In R. Y. Jennings, The Acquisition of Territory in International Law (pp. 1-13). Manchester: Manchester University Press.

Kohen, M. G., \& Hébié, M. (2013). Territory, Acquisition. In R. Wolfrum (Ed.), Max Planck Encyclopedia of Public International Law. London: Oxford University Press. 
Kolla, E. J. (2017). Sovereignty, International Law, and the French Revolution. Cambridge: Cambridge University Press. https://doi.org/10.1017/9781316832240

Lauterpacht, H. (1927). Private Law Sources and Analogies in International Law. London: Longmans, Green, \& Co.

Lawrence, T. J. (1895). The Principles of International Law. London: Macmillan \& Co.

Locke, J. (1988). Two Treatises of Government (ed. P. Laslett). Cambridge: Cambridge University Press. https://doi.org/10.1017/CBO9780511810268

Maine, H. S. (1890). International Law. London: John Murray.

McHugo, J. (1998). How to Prove Title to Territory. Boundary and Territory Briefing, 2, $1-23$.

McNeil, K. (2019). Flawed Precedent: The St. Catherine's Case and Aboriginal Title. Vancouver: UBC Press.

Menon, P. K. (1994). Title to Territory: Traditional Modes of Acquisitions by States. Revue de droit international, de sciences diplomatiques, politiques, et sociales, 72, 1-54.

Nesi, G. (2018). Uti possidetis Doctrine. In R. Wolfrum (Ed.), Max Planck Encyclopedia of Public International Law. Oxford: Oxford University Press.

Nuzzo, L. (2017). Territory, Sovereignty and the Construction of the Colonial Space. In M. Koskenniemi, W. Rech, \& M. Jiménez Fonseca (Eds.), International Law and Empire: Historical Explorations (pp. 263-292). Oxford: Oxford University Press. https://doi.org/10.1093/acprof:oso/9780198795575.003.0012

O'Keefe, R. (2011). Legal Title versus Effectivités: Prescription and the Promise and Problems of Private Law Analogies. International Community Law Review, 13, 147-188. https://doi.org/10.1163/187197311X555223

Oppenheim, L. (1920). International Law: A Treatise (3rd ed.) London: Longmans, Green \& Co.

Painter, J. (2010). Rethinking Territory. Antipode, 42, 1090-1118. https://doi.org/10.1111/j.1467-8330.2010.00795.x

Phillimore, R. (1857). Commentaries upon International Law. Philadelphia, PA: T. \& J.W. Johnson \& Co.

Pufendorf, S. (2005). Of the Law of Nature and Nations (tr. M. Carew, 4th ed.). London: J. Walthoe, et al., 1729; repr. Clark, NJ: Lawbook Exchange.

Pufendorf, S. (2006). Two Books of the Elements of Universal Jurisprudence (ed. T. Behme). Indianapolis, IN: Liberty Fund.

Ratner, S. R. (1996). Drawing a Better Line: Uti Possidetis and the Borders of New States. American Journal of International Law, 90, 590-624. https://doi.org/10.2307/2203988

Reynolds, H. (1996). Aboriginal Sovereignty. St. Leonards: Allen \& Unwin.

Servant-Le Priol, C. (2015). L'Acquisition du titre territorial: La notion de terra nullius chez Francisco de Vitoria, Emer de Vattel, et Lassa Oppenheim. In Claire Crépet Daigremont (Ed.), Grandes pages du droit international, Vol. 1, Les sujets (pp. 43-65). Paris: Pedone.

Sharma, S. P. (1997). Territorial Acquisition, Disputes, and International Law. The Hague: Nijhoff.

Shaw, M. N. (2005). Introduction: The International Law of Territory: An Overview. In M. N. Shaw (Ed.), Title to Territory (pp. 11-35). Aldershot: Dartmouth Ashgate.

Shaw, M. N. (2006). The Acquisition of Title in Nineteenth Century Africa: Some Thoughts. In P.-M. Dupuy et al. (Eds.), Völkerrecht als Weltordnung: Festschrift für 
Christian Tomuschat (pp. 1029-1049). Kehl: Engel Verlag.

Slatterly, B. (2007). The Metamorphosis of Aboriginal Title. Canadian Bar Review, 85, 255-286.

Starke, J. G. (1965-66). The Acquisition of Title to Territory by Newly Emerged States. British Year Book of International Law, 41, 411-416.

Strauss, M. J. (2015). Territorial Leasing in Diplomacy and International Law. Leiden: Brill Nijhoff. https://doi.org/10.1163/9789004293625

Twiss, T. (1884). The Law of Nations Considered as Independent Communities (2nd ed.). Oxford: Clarendon.

Van der Linden, M. (2014). The Acquisition of Africa (1870-1914): The Nature of 19th-Century International Law. Oisterwijk: Wolf Legal Pub.

Vattel, E. de. (2008). The Law of Nations (ed. B. Kapossy and R. Whatmore). Indianapolis, IN: Liberty Fund.

Verzijl, J. H. W. (1970). International Law in Historical Perspective, Vol. 3, State Territory. Leiden: Sijthoff.

Vitoria, F. de. (1991). On the American Indians (De Indis). In A. Pagden, \& J. Lawrance (Eds.), Political Writings (pp. 231-292). Cambridge: Cambridge University Press. https://doi.org/10.1017/CBO9780511840944.012

Westlake, J. (1894). Chapters on the Principles of International Law. Cambridge: Cambridge University Press.

Wheaton, H. (1815). A Digest of the Law of Maritime Captures and Prizes. New York: R. M'Dermut \& D.D. Arden.

Wheaton, H. (1936). Elements of International Law (ed. G.G. Wilson, from the 1866 ed. of R.H. Dana, Jr.). Oxford: Clarendon; London: Humphrey Milford.

Wolff, C. (1934). Jus Gentium Methodo Scientifica Pertractatum (tr. J.H. Drake). Oxford: Clarendon; London: Humphrey Milford.

Woolsey, T. D. (1874). Introduction to the Study of International Law (4th ed.). New York: Scribner, Armstrong \& Co.

Young, C. W. (1931). The International Legal Status of the Kwantung Leased Territory. Baltimore, MD: Johns Hopkins University Press. 